\title{
SUBMISSÃO OBRIGATÓRIA À IDENTIFICAÇÃO DO PERFIL GENÉTICO PARA FINS CRIMINAIS: UMA ABORDAGEM A LUZ DO DIREITO À INTIMIDADE E DA DIGNIDADE DA PESSOA HUMANA
}

\section{MANDATORY SUBMISSION TO THE IDENTIFICATION OF GENETIC PROFILE FOR CRIMINAL PURPOSE: A BROACH PURSUANT TO THE RIGHT TO PRIVACY AND DIGNITY OF THE HUMAN PERSON}

\author{
${ }^{1}$ George Maia Santos \\ ${ }^{2}$ Pedro Durão
}

\section{RESUMO}

O presente artigo tem por finalidade demonstrar que a submissão obrigatória de condenados por crime praticado, dolosamente, com violência de natureza grave contra pessoa, ou por crime hediondo, à identificação do perfil genético, mediante extração de DNA ácido desoxirribonucleico, ainda que por técnica adequada e indolor, é ofensiva a direitos fundamentais. Para tanto, parte-se do conceito geral do direito à intimidade, o qual se configura como um direito negativo ou de proteção contra as ingerências ilegítimas do Estado, visto proteger uma necessidade ou um bem básico para a livre autodeterminação individual. Em seguida, define-se a intimidade genética como sendo um patrimônio capaz de revelar as características físicas, psíquicas, comportamentais e de enfermidade, que, se revelados ou acessados sem o consentimento do imputado, poderão gerar a estigmatização e descriminação do sujeito envolvido, violando-se, desse modo, o direito à intimidade. Em linhas de conclusão, caminha-se no sentido de enfatizar que além do direito à intimidade, o fornecimento compulsório de material biológico para identificação do perfil genético é ofensivo aos direitos fundamentais à liberdade física ou ambulatorial; à integridade física; à liberdade religiosa ou de consciência; a não descriminação; ao silêncio e a não produção de prova contra si mesmo, e, em última instância, ao vetor maior de todos os direitos fundamentais: a dignidade da pessoa humana.

Palavras-chave: Perfil genético, Direito à intimidade, Direito a dignidade da pessoa humana

\footnotetext{
${ }^{1}$ Mestrando em Direito na Universidade Federal de Sergipe - UFS, São Cristóvão - SE (Brasil). Professor da Associação de Ensino e Cultura Pio Décimo, AECPD. Aracaju-SE (Brasil).

E-mail: gmaia@infonet.com.br

${ }^{2}$ Doutor em Direito pela Universidade de Buenos Aires - UBA, Buenos Aires, Argentina. Professor da Universidade Federal de Sergipe - UFS, São Cristóvão - SE (Brasil).

E-mail: pedrodurao@viajuridica.com.br
} 


\begin{abstract}
This article aims to demonstrate that the mandatory submission convicted of a crime committed, intentionally, with serious violence against person or heinous crime, to identify the genetic profile by DNA extraction - deoxyribonucleic acid, although by proper and painless technique is offensive to fundamental rights. For this purpose, it is part of the overall concept of the right to privacy, which is configured as a negative right or protection against unlawful state mismanagement, in order to protect a need or a basic right to the free individual selfdetermination. Then genetic intimacy is defined as an asset able to reveal the physical, psychological, behavioral and disease features, which, if disclosed or accessed without the consent of the accused, may generate stigmatization and discrimination of the subject involved, violating in this way, therefore, the right to privacy. In conclusion, we move towards emphasizing besides the right to privacy, compulsory provision of biological material to identify the genetic profile is offensive to fundamental rights to physical liberty or outpatient; physical integrity; to the freedom of religion or conscience; non-discrimination; the silence and non-production of evidences against himself, and in last instance, the biggest vector of all fundamental rights: the dignity of the human person.
\end{abstract}

Keywords: Genetic profile, Right to privacy, Right to human dignity 


\section{INTRODUÇÃO}

Nenhum problema social mobiliza tanto a opinião pública quanto a criminalidade. Geradora da violência e da insegurança pública está inserida no cotidiano da sociedade brasileira e, mais do que um problema, torna-se um fato condicionante da vida das pessoas.

Os custos da criminalidade são altíssimos. A mídia, por sua vez, dando uma roupagem novelística à violência criminal, faz a explosão da criminalidade tomar conta do imaginário social. A informação constante e ininterrupta manipula a consciência das pessoas. Todos se sentem inseguros. A sociedade mobiliza-se e o poder público é instado a agir. O "risco" torna-se o problema central a ser enfrentado.

Por tal motivo, o direito penal volta a ser mais uma ferramenta de controle social utilizada pelo poder constituído, vendo-se obrigado a, no mínimo, trazer soluções, ainda que paliativas, que sejam capazes de aplacar o sentimento de insegurança social.

Nesse cenário, a submissão de condenados por crimes dolosos, praticados com violência de natureza grave contra a pessoa, ou hediondos, à identificação obrigatória do perfil genético, e posterior armazenamento em bancos de dados, apresenta-se como uma solução tentadora, capaz de colocar fim aos riscos e à violência do mundo contemporâneo.

Vislumbra-se, contudo, que a criação de bancos de dados dos perfis genéticos, longe de ser uma criação para acalmar o clamor social, ganha um caráter preventivo, de impedir a conduta criminosa, principalmente em crimes seriais.

Com a tecnologia a favor da identificação criminal, a criação de referidos bancos tornou-se realidade corriqueira, e o sucesso do seu uso nos Estados Unidos e em países da Europa aumentou as expectativas quanto à solução de casos que antes eram vistos como irresolvíveis.

Apesar, porém, de constituir um importantíssimo instrumento de técnica investigativa, no campo criminal a polêmica se instaura, na medida em que enseja, com fundamentos biológicos, violações a direitos fundamentais relacionados à intimidade, e, numa dimensão axiológica, à dignidade da pessoa humana, o que, diga-se, é a finalidade desse ensaio demonstrar.

Nessa perspectiva, não tendo, por óbvio, a intenção de esgotar o tema, a pesquisa realizada é de cunho exploratório. Quanto à metodologia, fez-se a opção pelo método dedutivo, entendendo ser a melhor opção para a reunião de assuntos que abrangem o 
tema, partindo-se de fundamentos gerais para particulares, para encontrar as conclusões decorrentes dessa lógica.

De referência ao procedimento técnico, adotou-se como tipo e técnica, o bibliográfico, uma vez que o artigo tem como base dados secundários, extraídos principalmente de livros e artigos científicos, além da legislação sobre o tema.

\section{DIREITO À INTIMIDADE GENÉTICA RESGUARDADA}

Com o advento da Lei n. 12.654/2012, a Lei de Execução Penal (Lei n.

7.210/84) foi acrescida do art. $9^{\mathrm{a}}-\mathrm{A}^{1}$ o qual, pela sua redação, determina a submissão obrigatória dos condenados por crimes praticados, dolosamente, com violência de natureza grave contra a pessoa ou hediondos, à identificação do perfil genético, mediante extração de DNA - ácido desoxirribonucleico, com posterior armazenamento em banco de dados sigiloso criado para tal fim. Aqui reside um dos panos de fundo desse trabalho, visto que ao assim determinar, a legislação declinada afronta diretamente a intimidade genética do sujeito investigado.

O direito à intimidade está previsto no art. $5^{\circ}$, inciso X, da Constituição Federal. Trata-se de uma manifestação da personalidade individual cujo conhecimento é reservado ao titular daquele direito, o qual pode exercer seu controle e evitar que terceiros tomem ciência de informações sobre sua esfera íntima.

É um direito inerente à pessoa, que não é preciso ser conquistado para possuí- lo nem se perde por desconhecê-lo. Nos dizeres de CARVALHO (2004, p. 54), "é o direito de interditar às demais pessoas o conhecimento dos pensamentos, emoções, sentimentos e sensações, bem como dos atos e acontecimentos que o titular não queira revelar aos outros".

Esse direito, que na Constituição Federal tem característica de direito fundamental, "apresenta raízes no direito ao respeito da liberdade da pessoa, que se

\footnotetext{
1 "Art. $9^{\mathrm{O}}$-A. Os condenados por crime praticado, dolosamente, com violência de natureza grave contra pessoa, ou por qualquer dos crimes previstos no art. $1^{\circ}$ da Lei $n^{\circ} 8.072$, de 25 de julho de 1990, serão submetidos, obrigatoriamente, à identificação do perfil genético, mediante extração de DNA - ácido desoxirribonucleico, por técnica adequada e indolor.

$\S 1^{\text {O }}$ A identificação do perfil genético será armazenada em banco de dados sigiloso, conforme regulamento a ser expedido pelo Poder Executivo.

$\S 2^{\mathrm{O}}-$ A autoridade policial, federal ou estadual, poderá requerer ao juiz competente, no caso de inquérito instaurado, o acesso ao banco de dados de identificação de perfil genético."
} 
encontra na base de todo tipo de convivência e de relações humanas" (SANCHEZ CARAZO, 2000, p. 233).

De acordo com SANCHEZ CARAZO (2000, p. 233),

\begin{abstract}
a intimidade seria a parte da vida privada que cada ser humano - por motivos sociais, educacionais ou da própria natureza humana - queira guardar para si de uma forma muito especial e que somente dará a conhecer, se decidir fazê- lo, a um círculo reduzido de pessoas nas quais tenha fé compartilhada e com as quais, por isso, formará um ambiente de "confidencialidade". No âmbito cultural, o centro da intimidade encontrase em nova vida interior - pensamentos, sentimentos, desejos, ideologias e crenças -, e algumas parcelas de nossa vida exterior - como relações íntimas, atos fisiológicos, etc., e na periferia, certos dados sobre nossa pessoa, entre eles os que estão relacionados com nossa procedência, tais como os dados genéticos.
\end{abstract}

Erigido à condição de direito universal com a Declaração Universal dos Direitos Humanos de 1948, a intimidade configura-se como um direito negativo ou de proteção contra ingerências ilegítimas, logo, no plano jurídico-constitucional isso significa estabelecer uma conexão entre o direito à intimidade e o conjunto de direitos e bens jurídicos constitucionalmente protegidos, em particular pelo art. $1^{\circ}$, inciso III, da Constituição Federal. Em suma, o direito à intimidade protege uma necessidade ou um bem básico para a livre autodeterminação individual.

É por essa vertente que as medidas interventivas, segundo SILVA (2014, p. 65),

atentam contra o direito à intimidade na medida em que o procedimento de ingerência expõe a pessoa identificada a outrem. Como tais medidas pressupõem uma ingerência no corpo humano, a intimidade corporal torna suscetível de ser violada, uma vez que a exibição de partes do corpo do identificado pode gerar constrangimentos pelo simples motivo de o indivíduo não querer que terceiros saibam da existência de cicatrizes, deformidades físicas ou, ainda, colocar à mostra suas cavidades corporais, como a boca, o ânus ou a vagina.

Por isso "a preocupação com a proteção jurídica do direito à intimidade tem crescido nas últimas décadas, em face da multiplicação e aumento da potencialidade dos procedimentos que podem vulnerá-la." (CASABONA, 1999, p. 58).

Nessa perspectiva de concepções, o conceito de intimidade genética é definido "como o direito a determinar as condições de acesso à informação genética, seja em forma de dados, informação ou qualquer elemento orgânico do qual possa inferir-se esta, excluindo a ingerência de terceiros no conhecimento respectivo e proibindo sua difusão." (RUIZ MIGUEL, 2001, p. 150). 
Nos ensinamentos de KNOPPERS (1994, p. 387-388), "a intimidade genética apresenta uma natureza 'tríptico-díptica', pois a informação genética é, por sua própria natureza, individual, familiar e universal". Por esse olhar, observa-se que a informação genética configura um aspecto muito concreto da conhecida intimidade genética, que pela sua natureza polimórfica apresenta três níveis de informação. No primeiro nível, a "identidade genética corresponderia à constituição genética da pessoa, sendo esse o nível que deve ser objeto de uma especial proteção, a fim de preservar o controle da pessoa sobre si." (CORCOY BIDASOLO, 2001, p. 39). O segundo nível é "relativo à individualidade genética, que se traduz na expressão fenotípica da pessoa, com suas propensões, predisposições e fatores de risco." (RODRÍGUEZ-DRINCOURT ÁLVAREZ, 2002, p. 122). E o terceiro nível, alusivo à integridade genética, "inscreve- se na esfera social da genética humana, operando no nível dos mecanismos de proteção socioeconômica e de concepção de política estatal para limitar a estigmatizarão e a discriminação." (RODRÍGUEZ-DRINCOURT ÁLVAREZ, 2002, p. 122).

Tal direito está previsto no art. 14, alínea "a"2, da Declaração Internacional sobre Dados Genéticos Humanos e "está relacionado com a proteção do desenvolvimento da personalidade da pessoa e sua autonomia para conhecer e revelar informações sobre a própria constituição genética." (SILVA, 2014, p. 66-67).

$\mathrm{Na}$ órbita internacional destacam-se, ainda, a Declaração Universal sobre o Genoma Humano e os Direitos Humanos da Unesco (art. $\left.7^{\circ}\right)^{3}$ e o Convênio relativo aos Direitos Humanos e Biomedicina do Conselho da Europa (art. 10) ${ }^{4}$. No plano nacional do Direito constitucional interno, a Constituição Federal tratou o genoma humano com um direito do meio ambiente, não havendo outra previsão expressa sobre o patrimônio genético.

Importa destacar que a Declaração Internacional sobre Dados Genéticos tem a finalidade de garantir o respeito da dignidade humana e a proteção dos direitos humanos e das

\footnotetext{
2 "Os Estados deverão desenvolver esforços no sentido de proteger, nas condições previstas pelo direito interno em conformidade com o direito internacional relativo aos direitos humanos, a vida privada dos indivíduos e a confidencialidade dos dados genéticos humanos associados a uma pessoa, uma família ou, se for caso disso, um grupo identificável."

3 "Dados genéticos associados a indivíduo identificável, armazenados ou processados para uso em pesquisa ou para qualquer outro uso, devem ter sua confidencialidade assegurada, nas condições estabelecidas pela legislação.

4 "Vida privada e direito à informação - 1 - Qualquer pessoa tem direito ao respeito da sua vida privada no que toca a informações relacionadas com a sua saúde. 2 - Qualquer pessoa tem o direito de conhecer toda a informação recolhida sobre a sua saúde. Todavia, a vontade expressa por uma pessoa de não ser informada deve ser respeitada."
} 
liberdades fundamentais na coleta, tratamento, uso e conservação das informações genéticas. Entretanto, sua aplicação não abrange o uso do exame genético para fins criminais ou de determinação de paternidade, os quais obedecerão aos limites previstos na legislação de cada país.

Não obstante, tal declaração não deixa de ser, de acordo com SILVA (2014, p. 66),

um importante marco orientador para a proteção das informações genéticas, sobretudo no que toca às recomendações sobre a confidencialidade dos dados do genoma humano, tal como a dissociação de dados de pessoa identificável e a privacidade das informações genéticas. Afinal, a análise do genoma humano pode revelar muito mais sobre o indivíduo do que a exposição física de partes do seu corpo, causando-lhe transtornos pessoais e familiares, além de estigmatizações e discriminações sociais.

De fato, a informação obtida ou que se poderia obter da realização de análises genéticas nas pessoas, levanta alguns problemas relativos a essa informação, seu acesso e utilização, vez que os interesses da pessoa afetada podem conflitar com outros interesses individuais ou coletivos relacionados à saúde e à segurança, mas também os de outra natureza como os econômicos.

"O acesso a esta informação dará conhecimento de aspectos muitos importantes da pessoa a que se refiram, atingindo de forma muito direta a sua esfera íntima, mas serão também de grande utilidade para proteger sua saúde e de sua descendência." (CASABONA, 1999, p. 56).

Vê-se, assim, que as informações obtidas com a análise do genoma humano são amplas, revelando doenças congênitas e características físicas do identificado e de seus familiares. Imagine-se, por exemplo, "que o teste aponte que a pessoa é portadora de uma grave enfermidade genética que ainda não se manifestou ou mesmo revele que seu perfil genético é incompatível com o de seus pais, concluindo que os genitores biológicos do identificado não são aqueles apresentados na sua certidão de nascimento". (SILVA, 2014, p. 66). Sem dúvida, haveria uma violação à intimidade pessoal e familiar.

No sentir de CASABONA (1999, p. 56),

a propagação descontrolada dos dados genéticos representaria um grave perigo, primeiramente, pelo risco de converter o ser humano em cidadão transparente, "de cristal", em segundo, por ficar suscetível de discriminações de todo tipo, de caráter familiar, pessoal, trabalhista, para pactuar seguros de vida, enfermidade ou de aposentadoria, para obter determinadas permissões oficiais, na obtenção de empréstimos, pois esse grupo de população defeituosa ou não apta, correria o risco de ser estigmatizada. 
Afirma, ademais, que os problemas assinalados,

podem afetar tanto a liberdade das pessoas (realização de análises genéticas sem contar com a vontade do interessado) como a sua própria intimidade (quando se tem acesso aos resultados, ainda que de forma legítima ou com fins ilícitos), ou a outros direitos fundamentais, tendo em vista os propósitos de utilização dessa informação, vez que pode se fazer dela uso abusivo, discriminatório ou desviado dos objetivos autorizados inicialmente (CASABONA, 1999, p. 57).

Diante dessa perspectiva, HAMMERSCHMIDT (2007, p. 126) argumenta

que o tratamento da informação genética coloca em tensão diversos direitos fundamentais reconhecidos na Constituição Federal, tais como o direito à dignidade e integridade das pessoas, pela possibilidade de modificar o patrimônio biológico delas; direito à liberdade e ao livre desenvolvimento da personalidade, pois a informação genética supõe o conhecimento de si mesmo e forma parte da realização como pessoa; o princípio da igualdade de oportunidades, vez que o conhecimento de predisposições genéticas de cada indivíduo poderá resultar em discriminações sociais e laborais.

Resta evidente que os bancos de dados genéticos podem constituir fonte de informação de todo o patrimônio genético da pessoa, revelando suas características físicas, psíquicas e comportamentais. Portanto, apesar de a Lei n. 12.654/2012, acrescentar o art. $5^{\text {a }}$-A, $\S 1^{\text {o }}$, na Lei n. $12.037 / 2009^{5}$, no qual se proíbe a revelação de traços somáticos ou comportamentais das pessoas, exceto determinação genética de gênero, esse critério é "lacônico e abstrato, pois não estabelece claramente o objeto da análise pericial, o que amplia as possibilidades de violação à intimidade da pessoa, principalmente se for admitido o acesso à integralidade do genoma humano". (SILVA, 2014, p. 67-68).

Não há dúvida que o uso inadequado da informação genética pode gerar perigos e preconceitos como discriminação ou prestigiar alguém por suas condições genéticas, bem como a perda ou a diminuição da capacidade de autodeterminação, ante a intromissão e o acesso não autorizados nas esferas e conhecimentos reservados.

Por isso, nos ensinamentos de CASABONA (1999, p. 57),

\footnotetext{
5 “Art. 5o-A. Os dados relacionados à coleta do perfil genético deverão ser armazenados em banco de dados de perfis genéticos, gerenciado por unidade oficial de perícia criminal.

$\S 10$ As informações genéticas contidas nos bancos de dados de perfis genéticos não poderão revelar traços somáticos ou comportamentais das pessoas, exceto determinação genética de gênero, consoante as normas constitucionais e internacionais sobre direitos humanos, genoma humano e dados genéticos."
} 
o princípio da liberdade e da autonomia do interessado deve ser o primeiro a ser garantido, implicando na liberdade inicial de decisão daquele e seu consentimento oportuno para submeter-se às provas analíticas correspondentes, e inclusive, para ceder amostras biológicas para que seja possível sua realização. Outra consequência jurídica originada é a necessidade de proteção dos dados genéticos como confidenciais e o correlativo dever de segredo por parte dos profissionais e de outras pessoas que, por qualquer motivo, tenham acesso à informação obtida. Por esse motivo, assegurar a confidencialidade dessa informação está em primeiro plano, como meio de proteção da vida privada - na qual se destaca a intimidade - e de outros direitos, e também como meio de prevenir condutas discriminatórias.

Nessa toada, em razão do princípio da autonomia, determina-se que o consentimento do investigado abarque também o controle sobre os dados genéticos obtidos. Esse direito do indivíduo de decidir por si mesmo "acerca da utilização de seus dados médicos e especialmente de seus dados genéticos, implica o direito de poder aceder aos mesmos, controlar sua existência e veracidade e autorizar sua revelação." (CORCOY BIDASOLO, 2001, p. 31).

$$
\text { Assim, CASABONA (1999, p. 61-62) }
$$

\begin{abstract}
nesse contexto, a intimidade encontra três suportes principais de proteção. O primeiro diz respeito à proteção da intimidade em sua manifestação, como abrigo da personalidade, refere-se à esfera da intimidade que fica direta e exclusivamente reservada ao próprio interessado ou à sua família e a proteção pode ser obtida através da proteção de certas manifestações do segredo e da própria intimidade, na esfera civil e penal. O segundo refere-se à proteção da intimidade em sua manifestação de confidencialidade compartilhada. São aqueles aspectos da intimidade que, por prescrição da lei ou pela própria natureza das relações interindividuais ou sociais, facultam o acesso a terceiros, mas que estão obrigados por lei a manter a confidencialidade. É o dever de segredo profissional ou funcional dos funcionários públicos e a infração a esse dever aparece com caráter geral tanto no âmbito civil, como penal. E por fim, o terceiro seria a proteção da intimidade em relação ao processamento de dados, através das novas tecnologias da informação e comunicação, onde o interessado deve dar a informação pessoal privada, mas possui certa capacidade de controle dessa informação, no mesmo sentido da chamada liberdade e identidade informáticas.
\end{abstract}

Verifica-se pelo explanado a existência de um sério debate jurídico e ético quanto à manutenção dos bancos de dados de perfis genéticos para fins de investigação criminal, principalmente quando o sujeito está obrigado a fornecer material genético para sua identificação, o que afronta na esfera geral o direito à intimidade e num prisma específico o direito à intimidade genética.

É certo que como todo direito fundamental, o direito à privacidade da informação genética não ganha contornos absolutos. No entanto, o acesso à informação genética de outrem e a admissão de exceções ao direito à intimidade encontram-se condicionados por um valor que serve como fundamento e limite a todos os direitos fundamentais: o respeito à dignidade da pessoa humana. 
Apesar de certo relativismo na ponderação de direitos fundamentais em conflito, a garantia de proteção do núcleo essencial dos direitos fundamentais aponta para a parcela do conteúdo de um direito sem a qual ele perde a sua mínima eficácia, deixando, com isso, de ser reconhecível como um direito fundamental. Com efeito, a limitação de um direito fundamental não pode privá-lo de um mínimo de eficácia.

De acordo com SARLET (2012, p. 411),

\begin{abstract}
a ideia fundamental deste requisito é a de que existem conteúdos invioláveis dos direitos fundamentais que se reconduzem a posições mínimas indisponíveis às intervenções dos poderes estatais, mas que também podem ser opostas - inclusive diretamente - a particulares, embora quanto a este último aspecto exista divergência doutrinária relevante. Mesmo quando o legislador está constitucionalmente autorizado a editar normas restritivas, ele permanece vinculado à salvaguarda do núcleo essencial dos direitos restringidos.
\end{abstract}

Desta feita, no aspecto em discussão, diante de todo o perigo que circunda a extração de material genético para a constituição de bancos de dados criados para este fim, a obrigatoriedade de cessão da amostra biológica encontra-se apartada do valor que, repitase, serve de fundamento e limite a todos os direitos fundamentais, qual seja: a dignidade da pessoa humana.

Portanto, a possibilidade de cessão de material genético para quaisquer fins não pode ser uma imposição, sob pena de afronta ao direito à intimidade, pois em razão dele o homem deve ser protegido em seu direito de não ver devassado o seu genótipo e inclusive de ignorar sua constituição quando assim o preferir.

\title{
3. VIOLAÇÃO A DIGNIDADE HUMANA: UMA OFENSA QUE VAI ALÉM DA INTIMIDADE
}

A Dignidade da Pessoa Humana representa mais do que um princípio construído pela história, acima de tudo, significa um valor que visa proteger o ser humano contra tudo que lhe possa levar ao menoscabo.

Trata-se de valor fundamental da ordem jurídica em várias ordens constitucionais que nutrem a pretensão de constituírem um Estado Democrático de Direito, pois a concepção jusnaturalista consagra que o homem, em virtude tão somente de sua condição humana e independentemente de qualquer outra circunstância, é titula de direitos que devem se reconhecidos e respeitados por seus semelhantes e pelo Estado. 
Pode-se dizer, então, que a dignidade existe independentemente de ser reconhecida pelo Direito, não havendo a necessidade de se buscar uma definição jurídica da dignidade da pessoa humana, embora o direito exerça papel crucial na sua proteção e promoção.

SARLET (2010, p. 27-29) ensina que a dignidade encontra-se latente em tudo que diz respeito à essência do ser humano. Caracteriza-se como uma qualidade intrínseca e indissociável de todo e qualquer ser humano, de forma que a destruição de um implicaria a destruição do outro, fazendo com que o respeito e a proteção da dignidade da pessoa constituam-se em meta permanente da humanidade, do Estado de

Direito.

De acordo com VIEIRA (2006, p. 67-68),

o princípio da dignidade da pessoa humana, expresso no imperativo categórico de Kant, refere-se substantivamente à esfera de proteção da pessoa enquanto fim em si, e não como meio para a realização de objetivos de terceiros. A dignidade afasta os seres humanos da condição de objetos à disposição de terceiros. A dignidade afasta os seres humanos da condição de objetos à disposição de interesses alheios. Kant contempla a dignidade humana como uma exigência de imparcialidade. Se todas as pessoas são um fim em si, todas devem ser respeitadas. E ser "fim em si" significa ser considerado como feixe de razão e sentimentos que não podem ser injustificadamente suprimidos.

Sob a ótica de uma ordem constitucional, HABERLE (2009, p. 81) assevera

\begin{abstract}
que a dignidade humana constitui a norma fundamental do Estado. Assim, uma constituição que se compromete com a dignidade humana lança os contornos da sua compreensão do Estado de Direito e estabelece uma premissa antropológicocultural. Nesse diapasão, respeito e proteção da dignidade humana como dever jurídico fundamental do Estado constitucional constitui a premissa para todas as questões jurídico-dogmáticas particulares.
\end{abstract}

Na ordem jurídica nacional, a Constituição Federal pátria elevou a dignidade da pessoa humana à condição de princípio estruturante de todo o nosso ordenamento jurídico. A importância dada a este princípio impõe compreendê-lo enquanto cláusula geral voltada à efetivação dos direitos fundamentais, capaz de nortear a unidade material de nossa carta magna.

Nesta senda, BARROSO (2003, p. 29-31) proclama que

\begin{abstract}
os princípios constitucionais figuram como uma síntese dos valores abrigados no ordenamento jurídico. Espelham a ideologia da sociedade, seus postulados básicos, seus fins. Os princípios dão unidade e harmonia ao sistema, integrando suas diferentes partes e atenuando tensões normativas. Servem de guia para o interprete, cuja atuação deve pautar-se pela identificação do princípio maior que rege o tema apreciado, descendo do mais genérico ao mais específico, até chegar à formulação da regra concreta que vai reger a espécie. Princípios contêm, portanto, uma maior carga valorativa, um fundamento ético, uma decisão política relevante, e indicam uma determinada direção a seguir.
\end{abstract}


Para SARLET (2010, p. 75),

\begin{abstract}
ao consagrar a dignidade da pessoa humana como um dos fundamentos do nosso Estado Democrático de Direito, no título dos princípios fundamentais, nossa Constituinte de 1988, além de ter tomado uma decisão fundamental a respeito do sentido, da finalidade e da justificação do exercício do poder estatal e do próprio Estado, reconheceu que é o Estado que existe em função da pessoa humana, e não o contrário, já que o ser humano constitui a finalidade precípua, e não meio da atividade estatal.
\end{abstract}

Com efeito, o princípio da dignidade da pessoa humana guarda íntima conexão com os direitos fundamentais, à medida que se configura como uma espécie de matéria- prima que reúne os direitos fundamentais. Nessa condição de valor e princípio normativo fundamental, ordena o reconhecimento e a proteção dos direitos fundamentais de todas as dimensões. Por isso, afirma SARLET (2010, p. 96-97), "os direitos fundamentais constituem explicitações da dignidade da pessoa".

Desta forma, continua o autor,

pode-se dizer que em cada direito fundamental se faz presente um conteúdo da dignidade da pessoa. A dignidade da pessoa humana, na condição de valor e princípio normativo fundamental, exige e pressupõe o reconhecimento e proteção dos direitos fundamentais de todas as dimensões. (SARLET, 2010, p. 96-97).

Assim, quando não reconhecidos ou desrespeitados os direitos fundamentais que são inerentes à pessoa humana, estar-se-á negando-lhe a própria dignidade. Nesse particular, não é difícil vislumbrar que submeter alguém a obrigatoriedade de ser identificado pelo seu perfil genético, mediante extração de DNA - ácido desoxirribonucleico, ainda que por técnica adequada e indolor, é não reconhecer direitos e garantias previstas no Texto Constitucional, e, como consequência, a própria dignidade da pessoa humana.

As medidas de intervenção corporal obrigatória implicam a sujeição da pessoa a procedimentos que têm por finalidade a obtenção de informações de relevância criminal, a partir do próprio corpo humano. Logo, a execução dessas medidas afeta, potencialmente, direitos fundamentais.

Inicialmente, quanto ao direito à liberdade física ou liberdade ambulatorial, pode-se afirmar que consiste na autodeterminação da pessoa para produzir movimentos físicos. Tratase de um direito que recebeu especial atenção no ordenamento jurídico brasileiro, já que sua previsão se faz presente não só na legislação infraconstitucional, mas também em vários dispositivos da Constituição Federal (art. 5, XLI, XLVI, "a", LIV, LXVI, LXVIII), e no seu prefácio. 
A restrição a esse direito é uma consequência inevitável das medidas de intervenção corporal, uma vez que sua execução provoca limitações ambulatoriais à pessoa, reduzindo sua liberdade ao espaço físico em que a ingerência corporal será realizada ou limitando seus movimentos corporais no instante em que a intervenção é promovida. Portanto, ainda que essa limitação seja por período insignificante de tempo, não se pode negar que existe uma vulneração à liberdade física da pessoa.

De igual modo, resta evidente a violação ao direito à integridade física. Este, diz respeito à inviolabilidade do corpo humano contra ingerências que possam causar danos à integridade corporal, funcional, bem como à saúde da pessoa. Protegem-se os atributos físicos do indivíduo contra lesões corporais, psíquicas e até morais, permitindo o livre e sadio desenvolvimento do ser humano.

Partindo desse olhar, SILVA (2014, p. 61) afirma:

\begin{abstract}
parece claro que as medidas intervencionistas são restrições ao direito à integridade física de uma pessoa, já que submetê-la à extração de sangue, inspeções nas cavidades corporais, exames de raio-X e ultrassonografia constituem intervenções que, em grau de intensidades diferentes, importam uma vulneração ao corpo humano, notadamente quando essas medidas ocorrem sem o consentimento do afetado. Logo, devem ser descartadas quaisquer ingerências que acarretem graves riscos para a saúde ou dores desnecessárias. Intervenções cirúrgicas para extrair objetos do estômago ou para a extração do líquido cefalorraquídeo são medidas que representam perigo à integridade física da pessoa, o que deslegitima o seu uso para fins penais.
\end{abstract}

De mais a mais, vale trazer à baila que a intervenção obrigatória poderá trazer ofensas ao direito de liberdade religiosa e de consciência. Trata-se de direitos individuais fundamentais que identificam a pessoa às suas concepções. Diante da pluralidade das manifestações de ordem religiosa, política e filosófica, a liberdade de escolha das próprias convicções é ponto importante para a formação da autonomia intelectual e para o desenvolvimento da personalidade. Considerando que o Brasil é um Estado laico, e, além disso, garante o direito à liberdade de consciência que se relaciona com a proteção que tem o indivíduo de formular juízos e ideias sobre si mesmo e sobre o meio externo que o circunda, o Estado não pode intervir nas concepções religiosas, políticas ou filosóficas dos cidadãos, o que implica o respeito as suas convicções.

Quando a medida interventiva, desse modo, atingir dogmas associados às crenças, devoções e convicções pessoais, esses direitos fundamentais serão violados. É o caso, por exemplo, da extração de sangue das "Testemunhas de Jeová" que defendem a proibição da manipulação do sangue pela Bíblia ou integrantes das tribos indígenas Yanomani e as 
Karitianas, para quem o sangue tem uma representação espiritual atrelada aos seus costumes e tradições, contrapondo-se às análises laboratoriais e seus resultados científicos.

Vale a pena enaltecer que "em decorrência dos conhecimentos relacionados ao genoma humano, aventa-se a possibilidade de se criar uma categoria de 'cidadãos de segunda classe', discriminados em razão de suas especificidades genéticas." (SILVA,

2014, p. 69). De acordo com SÁ e NAVES (2009, p. 196), "trata-se de uma discriminação que se instaura pela determinação de características genéticas, fazendo com que um indivíduo seja escolhido ou preterido em virtude de sua formação congênita".

O direito a não discriminação está previsto nos arts. $3^{\circ}$, inciso IV e $5^{\circ}$, inciso XLI, da Constituição Federal, mas também pode ser interpretado como uma decorrência do direito fundamental à igualdade, o qual veda qualquer prática discriminatória que atente contra a dignidade humana. Além disso, o art. $7^{\circ}$, alínea "a" , da Declaração Internacional sobre os Dados Genéticos Humanos, e o art. $6^{07}$ da Declaração Universal sobre o Genoma Humano e os Direitos Humanos, fazem menção expressa a esse direito.

Vê-se que a discriminação em comento está intimamente ligada ao acesso aos dados genéticos. No âmbito criminal, o uso indevido de informações genéticas pode gera discriminações de contornos preocupantes.

"A possibilidade de aplicar terapias profiláticas realizadas por meio de manipulações genéticas em criminosos é uma realidade". (SILVA, 2014, p. 70). A partir do momento que se identifica um gene associado a um tipo de delito, abrem-se as portas para que o Estado promova sua cura, neutralização ou simplesmente a eliminação de seus portadores, de modo que a atuação estatal não se limite ao aspecto repressivo, mas também profilático, agindo sobre potenciais criminosos a fim de prevenir futuros delitos.

Aliado a tal situação, enseja-se a seletividade de criminosos em razão do seu perfil genético de forma a se ver aplicado o questionável Direito Penal do Autor, ou até mesmo o discurso lombrosiano.

\footnotetext{
6 "Deverão ser feitos todos os esforços no sentido de impedir que os dados genéticos e os dados proteómicos humanos sejam utilizados de um modo discriminatório que tenha por finalidade ou a dignidade humana de um indivíduo, ou para fins que conduzam à estigmatização de um indivíduo, de uma família, de um grupo ou de comunidade."

7 "Nenhum indivíduo deve ser submetido a discriminação com base em características genéticas, que vise violar ou que tenha como efeito a violação de direitos humanos, de liberdades fundamentais e da dignidade humana."
} 
O Direito Penal do Autor coaduna com a ideia de que o desvalor de um crime está em características que residem no autor em virtude de uma situação de inferioridade moral, biológica ou psicológica. O que se analisa para a aplicação da pena, conforme tal teoria, é a periculosidade do agente criminoso e não a danosidade da conduta praticada. Conforme os defensores da corrente o criminalizado é um ser inferior e, por isso, se vê apenado (inferioridade moral; estado de pecado; inferioridade mecânica; estado perigoso) numa negação da condição humana do indivíduo. Nas palavras de BATISTA e ZAFFARONI (2011, p. 132) "o direito penal do autor parece o produto de um crítico desequilibrado da dignidade humana daqueles que o sofrem e o praticam".

Não bastando isso, a criação de banco de dados de perfis genéticos apenas de condenados por crimes dolosos com violência grave contra a pessoa ou por crimes hediondos, favorece a política do etiquetamento penal, já levando a sociedade a chamá- los de criminosos, no contexto lombrosiano, dando tratamento policial a problemas sociais.

Em linhas finais, resta violado o direito ao silêncio consagrado no art. $5^{\circ}$, inciso LXIII, da Constituição Federal, o qual assegura ao imputado permanecer calado e a não produzir provas contra si mesmo (nemo tenetur se detegere). Tal direito também encontra albergue no art. $8^{\circ}, 2$, "g" $^{8}$, da Convenção Americana sobre Direitos Humanos, na qual se declara o direito de toda pessoa de "não ser obrigada a depor contra si mesma, nem a confessar-se culpada".

Para LOPES JÚNIOR (2013, p. 243), "a Lei n. 12.654/2012 mudou radicalmente a situação jurídica do sujeito passivo no processo penal, acabando com o direito de não produzir este tipo de prova contra si mesmo, fulminando a tradição brasileira de respeitar o direito de defesa pessoal negativo - nemo tenetur se detegere - relação a esse tipo de prova".

\footnotetext{
8 "Toda pessoa acusada de um delito tem direito a que se presuma sua inocência, enquanto não for legalmente comprovada sua culpa. Durante o processo, toda pessoa tem direito, em plena igualdade, às seguintes garantias mínimas: [...]

g) direito de não ser obrigada a depor contra si mesma, nem a confessar-se culpada; [...]"
} 
Desse modo, se é direito da pessoa não produzir provas contra si mesma, o sujeito não estaria obrigado a participar de uma atividade que lhe possa ser prejudicial. Ora, a intervenção corporal demanda a participação física da pessoa em um procedimento cujo resultado pode ensejar futura condenação, já que o seu perfil genético ficaria cadastrado em um banco de dados para futuro confronto, de maneira que o indivíduo estaria cooperando coercitivamente com uma atividade conflitante com os seus interesses.

Portanto, para além de ofensa ao direito à intimidade e à intimidade genética, a obrigatoriedade de submissão do indivíduo condenado por crimes dolosos, praticados com violência de natureza grave a pessoa, ou por quaisquer dos crimes considerados hediondos, constitui-se numa violação direta a outros direitos fundamentais aqui discorridos, e como consequência, ao vetor maior que condiciona as ações do Estado e o fundamento e limite de todos os direitos fundamentais: o respeito à dignidade da pessoa humana.

\section{CONSIDERAÇÕES FINAIS}

Resta evidente que a criminalidade crescente é um dos problemas sociais que nas últimas décadas tem mobilizando a sociedade brasileira em busca de uma solução. Os riscos causados pela "onda" de violência e a sensação da insegurança pública, tem ampliado o debate político acerca do tema, forçando o poder público, de certo modo, a implementar políticas públicas com o fim de minorar os elevados custos trazidos pelo crime em grande escala.

Diante disso, buscando dar uma resposta à problemática, a fim de garantir proteção ao povo, de paz e de tranquilidade na convivência social, o Estado brasileiro elege o Direito penal como ferramenta não apenas de controle, mas, também, de banimento das cifras da criminalidade. Assim, aliada a uma tendência repressora, mais e mais leis penais são postas no ordenamento jurídico para justificar a resposta estatal.

Nesse cenário, introduziu-se na legislação penal brasileira a Lei $n$. 12.654/2012, que prevê a coleta de perfil genético como forma de identificação criminal, bem como a criação de um banco de dados de perfis genéticos para fins criminais.

Porém, apesar de constituir um importante instrumento de técnica investigativa, ao impor a obrigatoriedade aos condenados por crimes hediondos ou praticados com violência de natureza grave a pessoa, a submeterem-se à identificação do perfil genético, mediante extração de DNA - ácido desoxirribonucleico, a normatização em 
epígrafe trouxe em seu bojo violações a direitos fundamentais relacionados à intimidade, e, numa dimensão axiológica, à dignidade da pessoa humana.

Assim, partindo-se de reflexões extraídas do direito à intimidade genética e ao valor constitucional dignidade humana, conclui-se:

a) diante de todo o perigo que circunda a extração de material genético para a constituição de bancos de dados criados para este fim, a obrigatoriedade de cessão de material biológico encontra-se apartada do valor que, repita-se, serve de fundamento e limite a todos os direitos fundamentais, qual seja: a dignidade da pessoa humana. Logo, a cessão de material genético para quaisquer fins, não pode ser uma imposição, sob pena de afronta ao direito à intimidade, visto que em razão dele o homem deve ser protegido em seu direito de não ver devassado o seu genótipo e inclusive de ignorar sua constituição quando assim o preferir;

b) as medidas de intervenção obrigatória implicam em violação ao direito à liberdade física ou liberdade ambulatorial, tendo em vista a sujeição da pessoa a procedimentos que têm por finalidade a obtenção de informações genéticas a partir do próprio corpo humano, sem qualquer conivência do imputado penalmente;

c) fica evidente a violação ao direito à integridade física, uma vez que as intervenções importam uma vulneração ao corpo, em grau de intensidades diferentes;

d) há ofensa ao direito de liberdade religiosa e de consciência, pois o acesso a extração de material biológico sem o consentimento do sujeito condenado, poderá atingir dogmas associados às crenças, devoções e convicções pessoais;

e) acarreta o afastamento do direito a não discriminação, na medida em que o conhecimento do genoma humano implica na criação de uma categoria de cidadãos pela determinação de suas características genéticas, fazendo com que um indivíduo seja escolhido ou preterido em virtude de sua formação congênita. Não bastasse isso, partindo de uma concepção lombrosiana e questionável do Direito Penal do Autor, instaura-se a seletividade do cidadão criminoso, abrindo-se a possibilidade de promoção de cura, neutralização ou simplesmente a eliminação de cidadãos com perfis genéticos específicos, evitando-se, assim, a prática de futuros delitos;

f) estabelece a cultura do etiquetamento penal, já que a criação de bancos de dados de perfis genéticos relaciona-se, apenas, aos condenados por crimes dolosos com violência grave contra a pessoa ou por crimes hediondos.

g) viola o direito ao silêncio e o de não produção de prova contra si mesmo, considerando que o cidadão está obrigado a participar de um procedimento, cujo resultado pode ensejar futura condenação, já que o seu perfil genético ficará cadastrado em um banco 
de dados para futuro confronto, de maneira que o indivíduo estaria cooperando coercitivamente com uma atividade conflitante com os seus interesses.

Assim, quando não reconhecidos ou desrespeitados os direitos fundamentais que são inerentes à pessoa humana, estar-se-á negando-lhe a própria dignidade. Nesse particular, não é difícil vislumbrar que submeter alguém a obrigatoriedade de ser identificado pelo seu perfil genético, mediante extração de DNA - ácido desoxirribonucleico, ainda que por técnica adequada e indolor, é não reconhecer direitos e garantias previstas no Texto Constitucional, e, como consequência, a própria dignidade da pessoa humana.

\section{REFERÊNCIAS BIBLIOGRÁFICAS}

BARROSO, Luis Roberto. Fundamentos teóricos e filosóficos do novo direito constitucional brasileiro. In: BARROSO, Luis Roberto (Org.). A nova interpretação constitucional: ponderação, direitos fundamentais e relações privadas. Rio de Janeiro: Renovar Boreal, 2003.

BATISTA, Nilo; ZAFFARONI, Eugenio Raúl; ALAGIA, Alejandro; SLOKAR, Alejandro. Direito penal brasileiro: teoria geral do direito penal. 4. ed. Rio de Janeiro: Revan, 2011. v. 1.

CARVALHO, Gisele Mendes de. Patrimônio genético e direito enal. Curitiba: Juruá, 2007.

CARVAlHO, Luis Gustavo Grandinetti Castanho de. Processo penal e constituição: princípios constitucionais do processo penal. 3. ed. Rio de Janeiro: Lumen Juris, 2004.

CASABONA, Carlos María Romeo. Do gene ao direito: sobre as implicações jurídicas do conhecimento e intervenção no genoma humano. São Paulo: IBCCRIM, 1999.

CORCOY BIDASOLO, Mirentxu. Medicina predictiva y discriminacion. Cuadernos de la Fundació Victor Grífols i Lucas. Barcelona: Fundació Victor Grifols i Lucas, 2001. n. 4.

HABERLE, Peter. A dignidade humana como fundamento da comunidade estatal. In: SARLET, Ingo Wolfgang (Org.). Dimensões da dignidade: ensaios de filosofia do direito e direito constitucional. 2. ed. Porto Alegre: Livraria do Advogado, 2009.

HAMMERSCHMIDT, Denise. Intimidade genética e direitos da personalidade. Curitiba: Juruá, 2007.

KNOPPERS, B. M. Hacia una intimidad genética. In: AA. VV. El Derecho ante el Proyecto Genoma Humano. Bilbao: Fundación BBY, 1994. v. 1. 
LOPES JÚNIOR, Aury. Direito processual penal. 10. ed. São Paulo: Saraiva, 2013. PÉREZ LUÑO, A. E. Derechos humanos, estado de derecho y constituición. In: GARCIA SAN MIGUEL, Luiz (Ed). Estudios sobre el derecho a la intimidad. Madrid: Tecnos, 1992.

RUIZ MIGUEL, Carlos. La nueva frontera del derecho a la intimidad. Revista de Derecho y Genoma Humano. Bilbao, n. 14, jan./jun. 2001.

SÁ, Maria de Fátima Freire de; NAVES, Bruno Torquato de Oliveira. Manual de Biodireito. Belo Horizonte: Del Rey, 2009.

SÁNCHEZ CARAZO, Carmen. La intimidad y el secreto médico. Madrid: Díaz de Santos, 2000 .

SARLET, Ingo Wolfgang. A eficácia dos direitos fundamentais. 8. ed. Porto Alegre: Livraria do Advogado, 2007.

SILVA, Emílio de Oliveira e. Identificação genética para fins criminais: análise dos aspectos processuais do banco de dados de perfil genético implementado pela Lei $\mathrm{n}$. 12.654/2012. Belo Horizonte: Del Rey, 2014.

VIEIRA, Oscar Vilhena. Direitos fundamentais: uma leitura da jurisprudência do STF. 4. ed. São Paulo: Atlas, 2006. 